\title{
Growth Response of Hydroponic Lactuca sativa L. to Application of Fertilizer Organic VIUSID Agro ${ }^{\circledR}$
}

\author{
Alexson Vieira Pordeus ${ }^{1}$, Lucas de Assis Moraes ${ }^{2}$, David de Oliveira Medeiros ${ }^{1} \&$ Letícia Carvalho Benitez ${ }^{1}$ \\ ${ }^{1}$ Unidade Acadêmica de Ciências Exatas e da Natureza, Centro de Formação de Professores, Universidade \\ Federal de Campina Grande, Cajazeiras, Paraíba, Brazil \\ ${ }^{2}$ Engenheiro Agrônomo, Cajazeiras, Paraíba, Brazil \\ Correspondence: Letícia Carvalho Benitez, Unidade Acadêmica de Ciências Exatas e da Natureza (UACEN), \\ Centro de Formação de Professores (CFP), Universidade Federal de Campina Grande (UFCG), Cajazeiras, \\ Paraíba, Brazil. Tel: 55-(83)-3532-2082. E-mail: leticia.carvalho@professor.ufcg.edu.br
}

Received: June 5, $2020 \quad$ Accepted: September 24, $2020 \quad$ Online Published: October 15, 2020

doi:10.5539/jas.v12n11p268 URL: https://doi.org/10.5539/jas.v12n11p268

\begin{abstract}
Lettuce (Lactuca sativa L.) production is a valuable crop for supporting family farms in the Brazilian semiarid region. The cultivation of this vegetable in a hydroponic system with foliar application of organic fertilizer can help in mitigating the challenges imposed by the region's edaphoclimatic conditions. Therefore, it is important to increase the lettuce production using new technologies. VIUSID Agro ${ }^{\circledR}$ is an example of such technology that has the potential to increase lettuce yields. VIUSID Agro ${ }^{\circledR}$ is a natural compound that actives molecular processes without affecting the environment adversely. This product acts as a natural bioregulator and is basically composed of amino acids, vitamins, and minerals. The experiment's objective was to analyze the impact of VIUSID Agro ${ }^{\circledR}$ organic fertilizer on the growth of hydroponic lettuce. The research was conducted on a family farm in Bom Jesus, Paraíba state, Brazil. The experimental was a completely randomized design with 5 VIUSID VIUSID Agro ${ }^{\circledR}$ concentrations $\left(0.0 ; 0.2 ; 0.4 ; 0.6\right.$ and $\left.0.8 \mathrm{~mL} \mathrm{~L}^{-1}\right)$ and 15 replications. Among the indicators evaluated were the plant length, leaf number, stem diameter, root length, and fresh and dry biomass. The results showed that the $0.4 \mathrm{~mL} \mathrm{~L}^{-1}$ VIUSID Agro ${ }^{\circledR}$ concentration produced greater growth than the control $\left(0.0 \mathrm{~mL} \mathrm{~L}^{-1}\right)$ for variables analyzed plant length, fresh and dry biomass of aerial portion, root length, fresh and dry biomass of root. The foliar application of VIUSID Agro ${ }^{\circledR}$ improved the performance of the lettuce morphological characteristics in a hydroponic cultivation system. Although this is the first Brazil research evaluating VIUSID Agro ${ }^{\circledR}$ as an organic fertilizer in hydroponic lettuce, results have shown promise.
\end{abstract}

Keywords: bioregulator, foliar fertilizing, hydroponic system, lettuce

\section{Introduction}

Vegetable production is currently involved generating farming income and employment in all Brazilian's regions. Among cultivated vegetables in Brazil and around the world, lettuce (Lactuca sativa L.) is a predominant and highly consumed vegetable (Henz \& Suinaga, 2009). L. sativa is an herbaceous vegetable belonging to the Asteraceae family from Asia, which was brought to Brazil by the Portuguese in 16th century (Resende et al., 2018).

Morphologically, it has leaves growing in a rosette format attached to a small stem. Lettuce leaves can vary between smooth to curly types, and with or without a head. Color-wise, lettuce can vary between green and purple, depending on the variety. Lettuce root systems are superficial and branched. Lettuce prefers a fertile well drained soil with ample organic matter and nutrients. The production cycle is considerably short, lasting 40-50 days (Filgueira, 2003). Certain lettuce varieties can produce several harvests a year, therefore, providing benefits from socioeconomic point of view. Nutritionally, lettuce has excellent levels of vitamins A and C, in addition to iron and phosphorus minerals (Resende et al., 2018).

In semiarid Brazil, lettuce cultivation is very important in supporting family farming. However, water scarcity, high temperatures, and soil degradation have been challenges for development lettuce species for such a region. The adoption of new technologies may serve to mitigate such challenges for lettuce production in semiarid Brazil. Therefore, hydroponics is one technological alternative that can be used for lettuce production. When it is 
possible to implement hydroponics, it can reduce the negative impacts on production and produce higher quality and more durability products compared to conventional production practices (Potrich et al., 2012).

Hydroponic cultivation is characterized by plant production without soil, where essential minerals and nutrients are provide through a growing solution. Because the hydroponic growing solutions are typically recycled, there is generally a total reduction in the water use produce a crop. In addition, advances in foliar fertilization can contribute to higher quality vegetable products, by correcting any nutritious deficiencies depending on the plant's physiological growth stage (Luz et al., 2010).

Among fertilizers used in L. sativa culture, the ones of organic origin differ of the industrialized chemical fertilizers, for not change the natural cycle of ecosystems what reduces the access to nutrients, water and oxygen by plants (Alcântara, 2016). VIUSID Agro ${ }^{\circledR}$ is an example of an organic fertilizer. It is a natural $100 \%$ vegetable product, which acts as a natural bioregulator. It is composed of amino acids, vitamins, and minerals, and produced by Catalysis Laboratory (Spain).

VIUSID Agro ${ }^{\circledR}$ promotes and activates the cell metabolism, by increasing both the plant's genetic potential and physiological activity. Furthermore, productivity increases as a result of more ideal growth and stronger plants as they relate to drought, frost, heat, insects, and, thereby decreasing the requirement for toxic non-organic products. The formulation compounds become molecularly activated resulting in the increase efficiency, without changing no modifying the molecular structure. However it is important to determine the impact and technology efficiency of VIUSID Agro ${ }^{\circledR}$ as it relates to increasing plant growth under hydroponic production systems. Therefore, we conducted research to determine the impact of VIUSID Agro $^{\circledR}$ on hydroponic lettuce growth in Brazilian semiarid region.

\section{Method}

The research was conducted at a family farm situated in a rural region in the town of Bom Jesus, Paraíba - Brazil $\left(38^{\circ} 39^{\prime} 00^{\prime \prime} \mathrm{W}, 06^{\circ} 49^{\prime} 01^{\prime \prime} \mathrm{S}\right)$. Climatological, the area is hot and semiarid. Day time temperatures are high and decrease during the evening. Annual temperatures vary from 23 to $30{ }^{\circ} \mathrm{C}$. Higher temperatures occur during the dry seasons (September-February) rainfall is typically low and irregular, with average annual rainfalls from 800 $\mathrm{mm}$.

The experiment was conducted in a covered greenhouse that was $5 \mathrm{~m}$ wide and $10 \mathrm{~m}$ long. The Nutrient Film Technique (NFT) was used for the hydroponic cultivation system. The nutritious solution was prepared according to Furlani (1998) for all treatments (Backes et al., 2004).

Water from the local dam was used for the experiment and analyzed by the Laboratório de Análises de Solo, Água e Planta (LASAP), in the Instituto Federal da Paraíba (IFPB, campus Sousa) (Table 1). Checking and adjustment of the $\mathrm{pH}(6.0 \pm 0.2)$ and of electric conductivity $\left[0.5 \mathrm{dS} \mathrm{m}^{-1}\right.$ germination phase $(0-7$ days $), 0.9 \mathrm{dS} \mathrm{m}^{-1}$ seedling phase (8-25 days), and $1.12 \mathrm{dS} \mathrm{m}^{-1}$ at mature phase (26-45 days)] in the nutritious solution were made every day.

The nutritious solution rotation was controlled by a timer regulated to work from the 6 am to $6 \mathrm{pm}$ period (15 min on, and $15 \mathrm{~min}$ off). In the evening, the timer was regulated to work from $6 \mathrm{pm}$ to 6 am (15 min on, and 60 min off).

Table 1. Physical-chemical analysis of the water used in hydroponic system

\begin{tabular}{|c|c|c|c|c|c|c|c|c|c|c|c|c|c|c|}
\hline pH & $\mathrm{CE}$ & $\mathbf{K}^{+}$ & $\mathrm{Na}^{+}$ & $\mathrm{Ca}^{+2}$ & $\mathbf{M g}^{+2}$ & $\mathrm{SO}_{4}{ }^{2-}$ & $\mathrm{CO}_{3}^{-}$ & $\mathrm{HCO}_{3}^{-}$ & $\mathrm{Cl}^{-}$ & CSR & $\mathrm{NaCl}$ & $\mathrm{CaCO}_{3}$ & RAS & Classe \\
\hline & $\mathrm{dSm}^{-1}$ & -- & --- & - & - & $\mathrm{mmol}_{\mathrm{c}}$ & & 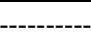 & - & ----- & ----- m & $\mathrm{L}^{-1}$----- & $\mathrm{mmol}_{\mathrm{c}} \mathrm{L}^{-1}$ & \\
\hline 7.4 & 0.24 & 0.4 & 0.8 & 0.20 & 0.40 & 0.01 & 0.0 & 4.68 & 0.8 & 4.08 & 124.3 & 126.0 & 1.47 & C1 S1 \\
\hline
\end{tabular}

Note. RSC: Residual sodium carbonate; SAS: Sodium adsorption; C1 S1: Water without risk in regard to soil salinization, viable for in water irrigation for most crops and soils. Under physical-chemical aspect, according to CONAMA Resolution 20, 20 July, 1986, the above sample is included in the acceptable range in regard to total solids dissolved (TSD) content with $153.6 \mathrm{mg} \mathrm{L}^{-1}$. According to Brazilian governmental regulation MS 2011/2014, the maximum value allowed is of $1000 \mathrm{mg} \mathrm{L}^{-1}$.

The lettuce variety used in the experiment was 'Soraia' (FELTRIN ${ }^{\circledR}$ seed company), which had $85 \%$ germination rate. Such variety presents advantage the resistance to Plasmopara viticola. The sowing was carried out in a phenolic cover with water where seedlings stayed for 15 days, being transplanting to the development bench. 
The experimental design was a completely randomized with by 5 treatments $\left(0.0,0.2,0.4,0.6\right.$, and $0.8 \mathrm{ml} \mathrm{L}^{-1}$ of VIUSID Agro ${ }^{\circledR}$ ) and 15 replications. The $0.0 \mathrm{~mL} \mathrm{~L}^{-1}$ treatment was the control concentration, while the $0.6 \mathrm{~mL}$ $\mathrm{L}^{-1}$ rate was the manufactory recommendation for leafy vegetables. Each treatment was applied to 15 different lettuce plants to analyze the growth variables.

The morphological data collected at $45 \mathrm{~d}$ after seeding. The data collected included the number of leaves per plant (except dry and yellow leaves), plant length $(\mathrm{cm})$, root length $(\mathrm{cm})$, stem diameter at the base of the stem $(\mathrm{mm})$, fresh and dry biomass of aerial portion, fresh and dry biomass of root. The dry biomass was determined after drying the biomass at $50^{\circ} \mathrm{C}$ for $72 \mathrm{~h}$.

Leaf application of VIUSID Agro ${ }^{\circledR}$ was performed using a hand sprayer. The first application was $16 \mathrm{~d}$ after seed sowing, during the morning hours weekly, resulting in a total of three applications.

Statistical analysis was carried out using WinStat software for Windows (Machado \& Conceição, 2002). The Kolmogorov-Smirnov test was used for normality. When normality existed, a simple analysis of variance (ANOVA) and Tukey test at 5\% probability level was used.

The VIUSID Agro ${ }^{\circledR}$ composition is presented in Table 2. All these compounds underwent a molecular activation prior to application.

Table 2. VISIUD Agro ${ }^{\circledR}$ composition

\begin{tabular}{|c|c|c|c|}
\hline Composition & g $100 \mathrm{~mL}^{-1}$ & Composition & $\mathrm{g} 100 \mathrm{~mL}^{-1}$ \\
\hline Potassium phosphate & 5 & Calcium pantothenate & 0.115 \\
\hline Malic acid & 4.6 & Pyridoxal & 0.225 \\
\hline Glucosamine & 4.6 & Folic acid & 0.05 \\
\hline Arginine & 4.15 & Cyanocobalamin & 0.0005 \\
\hline Glycine & 2.35 & Monoammonium glycyrrihizinate & 0.23 \\
\hline Ascorbic acid & 1.15 & Potassium sorbate & 0.2 \\
\hline Zinc sulfate & 0.115 & Sodium benzoate & 0.2 \\
\hline Distilled water-quantum sufficit (q.s.) & $100 \mathrm{~mL}$ & Triptofano & 0.5 \\
\hline
\end{tabular}

Source: Peña et al. $(2017,2018)$.

\section{Results and Discussion}

The analysis of variance indicated significant differences $(p<0.05)$ among concentrations of VIUSID Agro ${ }^{\circledR}$ for all the variables measured. The number of leaves (NL) was significantly greater for the $0.4 \mathrm{~mL} \mathrm{~L}^{-1}$ and the control treatments compared to the other treatments, both averaged 8 leaves per plant (Table 3 ). The leaf number was not significantly different among the other three treatments $\left(0.2,0.6\right.$, and $\left.0.8 \mathrm{~mL} \mathrm{~L}^{-1}\right)$, the $0.8 \mathrm{~mL} \mathrm{~L}^{-1}$ treatment was $31.2 \%$ less than the control treatment (Table 3).

Our leaf number results are in contrast to those observed by Peña et al. (2017), who observed a 15\% increase in leaf numbers when lettuce plants were treated with VIUSID Agro $^{\circledR}$ in contrast to the control. The leaf number differences between the 2 experiments may be due to the different production systems used, hydroponics vs. organoponics. Also the edaphoclimate and varieties may have played roles in the result differences.

Sediyama et al. (2016), in analyzing the productivity of American lettuce, grown in soil with different organic fertilizers from animal and vegetable origins, verified that there were no significant differences among treatments in respect to number of leaves. In contrast, Pereira et al. (2010), in analyzing the performance of lettuce Veronica, cultivated in field as response to different doses of foliar biofertilizer, determined that $20 \%$ concentration presented a significant impact on the numbers of leaves for in all development periods analyzed.

The VIUSID Agro ${ }^{\circledR}$ positive effect was observed for plant length (PL) where all treatments were statistically greater than the control treatment (Table 3). Lettuce plant lengths (PL) for the 0.8 and $0.4 \mathrm{~mL} \mathrm{~L}^{-1}$ treatments were $38 \%$ and $36 \%$ greater than the control, respectively.

According to Luz et al. (2006), lettuce is the most consumed leaf vegetable by Brazilians, while tomatoes are the most preferred vegetable fruit for salads. Therefore, the number of lettuce leaves is priority for this commercial crop. When combining the results for the number of leaves (NL) and plant lengths (PL), the $0.4 \mathrm{~mL} \mathrm{~L}^{-1}$ concentration produced best plants overall (Table 3). The $0.4 \mathrm{~mL} \mathrm{~L}^{-1}$ concentration had a similar number of leaves (NL) and greater plant lengths (PL) than the control. These results are similar to others who observed a 
positive impact of VIUSID Agro ${ }^{\circledR}$ on the aerial morphological characteristics for lettuce (Peña et al., 2017), radish (Raphanus sativus L.) (Peña et al., 2018) and turnip (Brassica rapa L.) (Calzada et al., 2019).

Pinto et al. (2017), conducting research with two American lettuce varieties with different organic fertilizer doses, determined that the varieties responded differently in the plant length. This is an example of how the lettuce phenotype may impact the plant's response to fertilizer applications.

VIUSID Agro ${ }^{\circledR}$ has compounds and elements which may have positively impacted the lettuce growth in our research. For example, amino acids like tryptophane, which are the component monomers of proteins and precursory in biosynthesis of some phytohormones such as auxin. These plant hormones act directly or indirectly on growth physiological mechanisms like cell extension. Research has shown that products that contain amino acids can benefit crop growth and quality of tomatoes (Solanum lycopersicum) (Boras et al., 2011) and soybean (Glycine max L.) (Saeed et al., 2005). Moreover, amino acids are bio-stimulants, and it is well known that the application of formulas containing amino acids have a positive effects on plant growth and yield, and significantly reduce abiotic stress injuries (Kowalczyk \& Zielony, 2008).

Table 3 shows the effect of treatments on the stem diameter (SD). Stem diameters followed a similar but not identical trend as the leaf number data. The control had a significantly greater average stem diameter than the all treatments containing VIUSID Agro ${ }^{\circledR}$. Among the VIUSID Agro ${ }^{\circledR}$ treatments, the $0.4 \mathrm{~mL} \mathrm{~L}^{-1}$ rate produced significantly greater stem diameters (SD) than the other treatments containing VIUSID Agro ${ }^{\circledR}$, but less than the $0.0 \mathrm{~mL} \mathrm{~L}^{-1}$ control. The highest VIUSID Agro ${ }^{\circledR}$ rate $\left(0.8 \mathrm{~mL} \mathrm{~L}^{-1}\right)$ produced the numerical smallest stem diameter $(4.93 \mathrm{~mm})$. Dias et al. (2009) determined that substituting biofertilizers in mineral solutions for hydroponic lettuce production were not effective in maintaining morphological growth parameters, including stem diameters.

Table 3. Number of Leaves (NL), Plant Length (PL), and Stem Diameter (SD) of lettuce plants, variety Soraia, treated with different concentrations of VIUSID Agro ${ }^{\circledR}$ organic fertilizer in a hydroponic production system

\begin{tabular}{llll}
\hline Concentration & \multicolumn{2}{c}{ Variables } \\
\cline { 2 - 4 } VIUSID Agro ${ }^{\left(\mathrm{mL} \mathrm{L}^{-1}\right)}$ & $\mathbf{N L}$ & $\mathbf{P L}(\mathbf{c m})$ & $\mathbf{S D} \mathbf{( m m})$ \\
\hline 0.0 & $8.0 \mathrm{a}^{*}$ & $13.91 \mathrm{c}$ & $7.40 \mathrm{a}$ \\
0.2 & $6.0 \mathrm{~b}$ & $17.56 \mathrm{~b}$ & $4.95 \mathrm{c}$ \\
0.4 & $8.0 \mathrm{a}$ & $18.88 \mathrm{a}$ & $5.95 \mathrm{~b}$ \\
0.6 & $6.0 \mathrm{~b}$ & $18.02 \mathrm{ab}$ & $4.96 \mathrm{c}$ \\
0.8 & $5.5 \mathrm{~b}$ & $19.17 \mathrm{a}$ & $4.93 \mathrm{c}$ \\
\hline Average & 6.76 & 17.50 & 5.64 \\
Variation coefficient & 13.70 & 6.44 & 14.24 \\
Deviation-standard & 0.92 & 1.13 & 0.80 \\
\hline
\end{tabular}

Note. * Averages followed by the same letter in a column are not significantly different by Tukey test $(\mathrm{P} \leq 0.05)$.

The fresh and dry biomass of the aerial portion of the lettuce plants are shown in Table 4 . The lettuce fresh and dry biomass aerial portions (FBAP \& DBAP) were significantly greater when treated with $0.4 \mathrm{~mL} \mathrm{~L}^{-1}$ VIUSID Agro $^{\circledR}$. Ojeda (2013) determined that a VIUSID Agro ${ }^{\circledR} 0.5 \mathrm{~mL} \mathrm{~L}^{-1}$ concentration applied to tobacco (Nicotiana tabacum L.) resulted in the optimum fresh biomass of the aerial portion. In addition, Penã et al. (2018) determined that radish dry biomass aerial portion significantly increased with VIUSID Agro ${ }^{\circledR}$ compared to the control.

Codognoto et al. (2015) determined that mineral fertilization produced greater American lettuce fresh and dry biomass for the aerial portion compared to the use of organic fertilizers. Candian et al. (2016) reported that the foliar application of biofertilizers with seaweed extracts and commercial hydrolyzed fish did not adversely affect American lettuce fresh biomass but did increase the dry biomass. A plant's total dry biomass production is a result of the plant's foliage efficiency in the interception and use of the solar radiation available during the growth cycle. Therefore, the VIUSID Agro ${ }^{\circledR}$ treatment in our experiment produced superior results than the control. 
Table 4. Fresh Biomass of Aerial Portion (FBAP) and Dry Biomass of Aerial Portion (DBAP) of lettuce plants, variety Soraia, treated with different concentrations of the organic fertilizer VIUSID Agro $\AA$ in a hydroponic production system

\begin{tabular}{lll}
\hline Concentration & \multicolumn{2}{c}{ Variables } \\
\cline { 2 - 3 } VIUSID Agro $^{\circledR}\left(\mathrm{mL} \mathrm{L}^{-1}\right)$ & FBAP $(\mathbf{m g})$ & DBAP $(\mathbf{m g})$ \\
\hline 0.0 & $0.470 \mathrm{~b} *$ & $0.279 \mathrm{~b}$ \\
0.2 & $0.391 \mathrm{c}$ & $0.233 \mathrm{c}$ \\
0.4 & $0.537 \mathrm{a}$ & $0.328 \mathrm{a}$ \\
0.6 & $0.447 \mathrm{bc}$ & $0.279 \mathrm{~b}$ \\
0.8 & $0.421 \mathrm{bc}$ & $0.262 \mathrm{bc}$ \\
\hline Average & 0.453 & 0.276 \\
Variation coefficient & 14.22 & 14.96 \\
Deviation-standard & 0.06 & 0.04 \\
\hline
\end{tabular}

Note. * Averages followed by the same letter in a column are not significant different by Tukey test $(\mathrm{P} \leq 0.05)$.

Table 5 shows the significant impact of the foliar applications of VIUSID Agro ${ }^{\circledR}$ organic fertilizer treatments on lettuce root system. The $0.4 \mathrm{~mL} \mathrm{~L}^{-1}$ treatment produced the best lettuce root development combined across all root variables. In each case (RL, RSFB, and RSDB), the $0.4 \mathrm{~mL} \mathrm{~L}^{-1}$ treatment was significantly greater than the control $\left(0.0 \mathrm{~mL} \mathrm{~L}^{-1}\right.$ VIUSID Agro $\left.{ }^{\mathbb{B}}\right)$. Compared to the control, the root length and fresh root biomass for the 0.4 $\mathrm{mL} \mathrm{L}^{-1}$ treatment was $19 \%$ and $33 \%$ greater than the control, respectively. These results are consistent with Peña et al. (2017) who observed an $18 \%$ increase in the lettuce root fresh biomass when treated with $0.4 \mathrm{~mL} \mathrm{~L}^{-1}$ of VIUSID Agro ${ }^{\circledR}$.

Costa et al. (2006) determined that a mineral hydroponic solution produced significant lettuce root growth, when comparing different nutrient solutions with either a mineral or animal origin. Pantano et al. (2010), in contrast, did not observe an impact of either chemical or biological fertilizers on lettuce (var. Julie) fresh root biomass.

Peña et al. (2015) determined that weekly foliar application of the VIUSID Agro® increased vegetative growth and accelerated flowering onset for Anthurium andreanum Lind (common names: flamingo flower, tail flower, painter's palette, and lace leaf).Other authors have also reported satisfactory results in several crops when using VIUSID Agro ${ }^{\circledR}$. These crops include grass (Galdo et al., 2014; Quintana et al., 2015), tomatoes (Peña et al., 2016), and corn and onions (Atta et al., 2017; Melendrez et al., 2016).

Table 5. Root Length (RL), Root System Fresh Biomass (RSFB), and Root System Dry Biomass (RSDP) of lettuce plants, variety Soraia, treated with different concentrations of VIUSID Agro ${ }^{\circledR}$ organic fertilizer in a hydroponic production system

\begin{tabular}{llll}
\hline $\begin{array}{l}\text { Concentration } \\
\text { VIUSID Agro }^{\circledR}\left(\mathrm{mL} \mathrm{L}^{-1}\right)\end{array}$ & \multicolumn{3}{c}{ Variables } \\
\cline { 2 - 4 } & RL (cm) & RSFB (mg) & RSDB (mg) \\
\hline 0.0 & $13.12 \mathrm{~b}^{*}$ & $0.230 \mathrm{~b}$ & $0.131 \mathrm{bc}$ \\
0.2 & $13.81 \mathrm{~b}$ & $0.272 \mathrm{ab}$ & $0.157 \mathrm{ab}$ \\
0.4 & $15.55 \mathrm{a}$ & $0.305 \mathrm{a}$ & $0.179 \mathrm{a}$ \\
0.6 & $14.05 \mathrm{ab}$ & $0.245 \mathrm{~b}$ & $0.135 \mathrm{bc}$ \\
0.8 & $13.57 \mathrm{~b}$ & $0.183 \mathrm{c}$ & $0.104 \mathrm{c}$ \\
\hdashline Average & 14.02 & 0.247 & 0.141 \\
Variation coeficiente & 11.95 & 16.80 & 21.71 \\
Deviation-standard & 1.67 & 0.04 & 0.03 \\
\hline
\end{tabular}

Note. * Averages followed by the same letter in column do not differ statistically among them by Tukey test $(\mathrm{P} \leq$ $0.05)$.

\section{Conclusions}

The weekly foliar applications of VIUSID Agro ${ }^{\circledR}$ at $0.4 \mathrm{ml} \mathrm{L}^{-1}$ to hydroponically grown lettuce plants (var. Soraia) produced better plants than the control. The foliar application of VIUSID Agro ${ }^{\circledR}$ at $0.8 \mathrm{ml} \mathrm{L}^{-1}$ is not 
recommended for lettuce plants grown in hydroponic. Although this is the first Brazilian research investigating VIUSID Agro ${ }^{\circledR}$ in hydroponic lettuce production, the results are promising and suggest additional research should be conducted.

\section{References}

Alcântara, F. A. de. (2016). Aspectos básicos sobre a produção local de fertilizantes alternativos para sistemas agroecológicos. Documentos Embrapa, 310 (p. 37). Editora Embrapa Arroz e Feijão, Santo Antônio de Goiás, GO. Retrieved from https://www.infoteca.cnptia.embrapa.br/infoteca/bitstream/doc/1051091/1/CNP AF2016dc310.pdf

Atta, M., Abdel-Lattif, M., \& Absy, R. (2017). Influence of Biostimulants Supplement on Maize Yield and Agronomic Traits. Bioscience Research, 14, 604-615. Retrieved from https://www.isisn.org/BR-14-2017/ 604-615-14(3)2017BR-1503.pdf

Backes, F. A. A. L., Santos, O. S. dos., Pilau, F. G., Bonnecarrère, R. A. G., Medeiros, S. L. P., \& Fagan, E. B. F. (2004). Nutrients replacement in nutrient solution for lettuce hydroponic cultivation. Ciência Rural, 34 , 1407-1414. https://doi.org/10.1590/S0103-84782004000500013

Boras, M., Zidan, R., \& Halloum, W. (2011). Effect of amino acids on growth, production and quality of tomato in plastic greenhouse. Tishreen Univ. J. for Research and Scientific Studies-Biol. Sci. Series, 33, 229-238. Retrieved from http://tishreen.edu.sy/sites/default/files/Tishreen_Magazine/14_28.pdf

Calzada, K. P., Viciedo, D. O., Calero, A., Rodríguez, J. C., Kukurtcu, B., Álvarez, Y. M. P., \& Salas, A. C. (2019). Productive response of Brassica rapa L. subsp. chinensis to application of VIUSID Agro. J. of Agricultural Sci. and Techn., 103-109. https://doi.org/10.17265/2161-6264/2019.02.003

Candian, J. S., Ferreira, R. de P., Martins, R. C., Lorenzetti, E. R., \& Bastiani, M. L. R. (2016). Biofertilizers in the production and characterization of Americana, Crespa and Mimosa lettuces. Vértices, 18, 233-244. https://doi.org/10.19180/1809-2667.v18n116-12

Codognoto, L. da C., Lima, A. A. de, Oliveira, D. J. L. S. F. de, Silva, C. G., Silva, E. A. da, \& Porto, M. O. (2015). Performance of cultivars of crisphead lettuce under management of mineral and organic fertilization. Revista Brasileira de Ciências Ambientais, 6(2). https://doi.org/10.21206/rbas.v6i2.308

Costa, N. E. da, Ribeiro, M. C. C., Lima, J. S. da S. de, Cardoso, A. A., \& Oliveira, G. L. (2006). Use of biofertilizante in the lettuce for the hidropônico system floating. Revista Verde, 1, 41-47. Retrieved from https://gvaa.com.br/revista/index.php/RVADS/article/viewFile/14/14

Dias, N. da S., Brito, A. A. F. de, Neto, O. N. de S., Lira, R. B. de, \& Brito, R. F. de. (2009). Hydroponic lettuce production using biofertilizer to prepare nutrient solutions. Revista Caatinga, 22, 158-162. Retrieved from https://periodicos.ufersa.edu.br/index.php/caatinga/article/view/1477

Filgueira, F. A. R. (2003). Novo manual de oleicultura: Agrotecnologia moderna na produção e comercialização de hortaliças (2nd ed., p. 412). Editora: Viçosa, MG: UFV.

Furlani, P. R. (1998). Instruções para o cultivo de hortaliças de folhas pela técnica de hidroponia-NFT. Documentos Instituto Agronômico de Campinas (IAC), 168 (p. 30). Campinas, SP.

Galdo, Y., Quintana, M., Cancio, T., \& Méndez, V. (2014). Use of Agro VIUSID to Stimulate Growth in Three Grasses. Memories III International Agrodesarrollo Convention 2014, Varadero, Cuba.

Henz, G. P., \& Suinaga, F. (2009). Tipos de alface cultivados no Brasil. Comunicado Técnico 75 (p. 7). Brasília, DF: Embrapa Hortaliças. Retrieved from https://www.infoteca.cnptia.embrapa.br/handle/doc/783588

Kowalczyk, K., \& Zielony, T. (2008). Effect of Aminoplant and Asahi on Yield and Quality of Lettuce Grown on Rockwool. Conference of Biostimulators in Modern Agriculture, Warsaw, Poland.

Luz, J. M. Q., Guimarães, S. T. M. R., \& Korndörfer, G. H. (2006). Hidroponic production of lettuce in hidroponic solution with or without silicon. Horticultura Brasileira, 24, 295-300. https://doi.org/10.1590/ S0102-05362006000300005

Luz, J. M. Q., Oliveira, G., Queiroz, A. A., \& Carreon, A. (2010). Foliar application of organic mineral fertilizer in lettuce. Horticultura Brasileira, 28, 373-377. https://doi.org/10.1590/S0102-05362010000300023

Machado, A., \& Conceição, A. R. (2002). Programa estatístico WinStat: Sistema de análise estatístico para Windows (Versão 2.0). Pelotas: UFPel. 
Melendrez, J. F., Peña, K., \& Cristo, M. (2016). Effect of Three Doses of VIUSID Agro on the Cultivation of Onion (Allium cepa L.) in the Municipality of Taguasco. Infociencia, 20, 1-12.

Ojeda, L. M. C. (2013). Utilización de VIUSID Agro, Bayfolán forte y FitoMas-E en el cultivo del tabaco (Nicotiana tabacum L.) en el municipio de Taguasco (p. 25). Facultad de Ciências Agropecuárias, Universidad de Sancti Spíritus. Retrieved from http://www.catalysisagro.com/viusid/pdf/qr/VIUSID_agroVIUSID_Agro-Bayfolan_forte-y-FitoMas-E_en_el_cultivo_del_tabaco-Cuba2013.pdf

Pantano, D. R. dos S., Junior, R. A., Reis, J. C. dos, \& Andreani, D. I. K. (2010). Adubação foliar em alface. Horticultura Brasileira, 28, 3824-3830. Retrieved from http://www.abhorticultura.com.br/EventosX/Traba lhos/EV_4/A2826_T4109_Comp.pdf

Peña K., Rodríguez, J. C., Viciedo, D. O., Hurtado, A. C., Meléndrez, J. F., \& Valdez, R. G. (2018). VIUSID Agro ${ }^{\circledR}$ dose effect on the morpho-physiological and productive behavior of radish (Raphanus sativus L.). Revista de la Facultad de Agronomia, 35, 293-317. Retrieved from http://hdl.handle.net/11449/171300

Peña, K., Rodriguez, J. C., \& Melendrez, J. F. (2015). Effect of the Application of a Molecularly Activated Growth Promoter in the Culture of Anthurium andreanum Lind. Granma Sci. J., 19, 1-12.

Peña, K., Rodriguez, J. C., \& Melendrez, J. F. (2016). The VIUSID Agro: An Alternative in the Increase of the Production of Tomato (Solanum lycopersicum L.). Caribbean Journal of Social Sciences, 15, 1-10.

Peña, K., Rodríguez, J. C., Olivera, D., Meléndrez, J., Rodríguez, L., García, R., \& Rodríguez, L. (2017). Effects of a growth promoter on different vegetable crops. International J. of Development Res., 7, 11737-11743. Retrieved from https://www.journalijdr.com/sites/default/files/issue-pdf/7818.pdf

Pereira, M. A. B., Silva, J. C. da, Mata, J. F. da, Silva, J. C. da, Freitas, G. A. de, Santos, L. B. dos, \& Nascimento, I. R. do. (2010). Foliar biofertilizer applied in cover fertilization in the production of lettuce cv. Veronica. Pesquisa aplicada \& Agrotecnologia, 2, 135-141. Retrieved from https://revistas.unicentro.br/ index.php/repaa/article/viewFile/823/1223\#page $=6$

Pinto, L. P., Korber, A. H. C., Neiverth, A., Tamke, R., Reckziegel, J. E., \& Fidler, K. (2017). Application of different doses of organic fertilizer of the bokashi type in two varieties of lettuce Lactuca sativa L. Revista Desafios, 4, 110-116. https://doi.org/10.20873/uft.2359-3652.2017v4n4p110

Potrich, A. C. G., Pinheiro, R. R., \& Schmidt, D. (2012). Hydroponic lettuce as an alternative to food production sustainable way. Enciclipédia Biosfera, Centro Cientifica Conhecer, 8, 36-48. Retrieved from https://www. conhecer.org.br/enciclop/2012b/ciencias\%20agrarias/alface.pdf

Quintana, M., Galdo, Y., Cancio, T., \& Mendez, V. (2015). Effect of the Natural Stimulant VIUSID Agro in the Production of Forage Biomass of Hybrid Brachiaria cv. Mulatto II. Agrotecnia of Cuba, 39, 15-22

Resende, G. M., Yuri, J. E., \& Costa, N. D. (2018). Cultivo de alface-crespa no Submédio do Vale do São Francisco. Instruções Técnicas da Embrapa Semiárido 134. Petrolina, PE. https://doi.org/10.14808/ sci.plena.2017.110201

Saeed, M. R., Kheir, A. M., \& Al-Sayed, A. A. (2005). Supperssive effect of some amino acids against Meloidogyne incognita on soybeans. J. of Agric. Sci. Mansoura Univ., 30, 1097-1103.

Sediyama, M. A. N., Magalhães, I. de P. B., Vidigal, S. M., de Oliveira Pinto, C. L., Cardoso, D. S., Marques Fonseca, M. C., \& Lopes de Carvalho, I. P. (2016). Effect of the organic fertilizer use on crisphead lettuce yield. Revista Brasileira de Agropecuária Sustentável, 6, 66-74. https://doi.org/10.21206/rbas.v6i2.308

\section{Copyrights}

Copyright for this article is retained by the author(s), with first publication rights granted to the journal.

This is an open-access article distributed under the terms and conditions of the Creative Commons Attribution license (http://creativecommons.org/licenses/by/4.0/). 